\title{
CHILD ABUSE AND NEGLECT AS PREDICTORS OF DEPRESSIVE TENDENCIES AMONG SECONDARY SCHOOL ADOLESCENTS IN IDEATO NORTH LOCAL GOVERNMENT AREA OF IMO STATE, NIGERIA
}

\author{
ISIGUZO BLESSING CHIOMA*, IGWE-OFOEKWE IFEOMA UGWUMSINACHI
}

\author{
Department of Educational Psychology, Guidance \& Counseling, University of Port Harcourt, Nigeria
}

*Emails: cisiguzo@gmail.com, umsydaniels@gmail.com

Received: 28 November 2020, Revised and Accepted: 11 January 2021

\begin{abstract}
This study investigated child abuse and neglect as predictors of depressive tendencies among adolescents in secondary schools in Ideato North Local Government Area (L.G.A.) of Imo State, Nigeria. The study adopted a correlational survey research design. Two research questions and two hypotheses were formulated to guide the study. The study population comprised all the public and private secondary school adolescents in Ideato North Local Government Area of Imo State. The population consists of thirteen thousand seven hundred and fifteen $(13,715)$ adolescent students in secondary schools. A sample of 1364 students was used for the study representing $10 \%$ of the entire population using the clustered sampling technique. A questionnaire titled Physical and Sexual Abuse Scale (PSAS) and Depressive Tendencies Scale (D.T.S.) were validated. The reliability coefficients of the instruments were 0.94 and 0.89 , respectively using Cronbach alpha statistics, which guarantee the use of the instruments for the study. The Pearson product-moment correlation coefficient was used to answer the research questions, while the two hypotheses were tested at a probability level of 0.05 using ANOVA. It was found out among others that physical and sexual abuses predict depressive tendencies among adolescent students. It was recommended that government should enact legislation against child abuse and neglect, there should be awareness programmes for children through a collaboration of parents and teachers/caregivers, principals should recognize the roles of educational psychologists and school counselors in the fight against sexual abuse and neglect, parents and guardians should also be properly enlightened through seminars and workshops by government and N.G.O.s to prevent and protect their children and wards against any forms of child abuse and neglect.
\end{abstract}

Keywords: Child abuse, Physical abuse, Sexual abuse, Neglect, Depressive tendencies, Secondary school adolescents.

(C) 2021 The Authors. Published by Innovare Academic Sciences Pvt Ltd. This is an open access article under the CC BY license (https://creativecommons.org/licenses/by/4.0/) DOI: https://dx.doi.org/10.22159/ijoe.2021v9i1.40387. Journal homepage: https://innovareacademics.in/journals/index.php/ijoe

\section{INTRODUCTION}

It is no more a controversy that children are the leaders of tomorrow and as such should be treated as important human elements in our society. This makes it is very pertinent for parents and guardians to protect their children and wards against abuse and neglect to avoid their psychological and general well-being from being truncated to a helpless and depressing condition. However, so many indigents and well to do parents are not living up to fulfilling their parenting roles, which has continuously caused an upsurge to child abuse and neglect. This problem has always been reported in the literature and mass media such as Facebook, internet, WhatsApp, print and non-print media, ranging from records of infanticide, genital mutilation, abandonment to other forms of violence against children which date back to ancient civilization. According to World Health Organization (2006), such records also contain reports of unkempt, weak and malnourished children cast out of families to fend for themselves, especially those of them who have been physically and or sexually abused. These children who have experienced this abuse and neglect are at risk for a number of problematic developmental, health and mental outcomes, including not only learning problems and peer problems but also internalizing symptoms such as depression and anxiety together with conduct disorder or aggression and post-traumatic stress disorder. As an adolescent, these children continue to exhibit increased risk for emotional disorders, substance use, serious medical illness, etc. This abusive care has consequences on their health and social, psychological and cognitive development.

A number of psychiatric syndromes feature depressed moods as the main symptom (National Institute of Mental Health, 2013). Mood disorders are a group of disorders considered to be primary disturbances of mood. These include major depressive disorder (M.D.D.), commonly called major depression or clinical depression, where a person has at least two weeks of a mood swing or a loss of interest or pleasure in nearly all activities; and dysthymia, a state of chronic depressed mood. A depressed adolescent child manifests social withdrawal. Another psychological symptom often seen in depression is psychomotor agitation/retardation. In psychomotor agitation, the person may pace or wing his or her hands, while in psychomotor retardation, the individual may have slowed speech or body movements. Additionally, feelings of worthlessness and guilt are commonly seen in depression. For example, depressed adolescents may be overly self-critical, exaggerate their responsibility for negative events, or focus on their personal failings. Finally, thoughts of death and suicidal behaviour are sometimes seen in individuals who are depressed. Indeed, depressed people may think about dying or suicide and, in some instances, may even attempt to take their lives. Based on these explanations, this study needs this study as adolescent secondary school students could be adversely affected by the conditions of child abuse and neglect.

\section{REVIEW OF THE RELATED LITERATURE}

The African Network for Prevention and Protection against Child Abuse and Neglect (2000) defines child abuse as the intentional, unintentional or well intentional act which engenders the physical health, emotional health, moral and educational welfare of children. Ettu, Ezeribe and Okpoko (2015) defined child abuse as that which causes or permits any harmful or offensive contact on the child's body. This also includes any form of communication or harassment that can humiliate, frighten, or shame the child.

Garba and Kantiok (2015) defined child abuse to involve both physical, sexual, emotional maltreatment and neglect. Physical abuse, according to Gelles (1973) can be simply described as deliberate or the result of excessive corporal punishment. Messer and Jones (2009) defined it as actual or likely physical injury to a child or failure to prevent physical injury to a child including deliberate poisoning, suffocation, kicking, burning, 
etc. Garba and Kantiok (2015) described it to be an act of being deliberately aggressive or inflicting of serious injuries or actions on a child by an adult. This can be in the form of infliction of physical injury by slapping, punching, beating, kicking, biting and shaking. It may also include the use of a weapon or any other object used to inflict harm. Physical abuse involves causing bodily injury to a child, including hitting and burning. Such actions are considered physically abusive whether or not the parent or caregiver intended to inflict injury. Exposing the child to danger through activities such as drunkness and reckless driving are also forms of physical abuse. The researchers consider it to be the infliction of harm on another person (a child), thereby causing the child to suffer pains.

Sexual abuse and exploitation involve any inappropriate sexual behaviour toward the child such as touching a child's genitals, sexual or anal intercourse, incest, rape, oral sex acts performed on the child or forcing the child to perform them (Waters \& Cummings, 2000). It also includes forcing the child to watch sexual acts performed by others, exposing a child to sexual materials or behaviours, or exposing or otherwise exhibiting one's genitals to the child, sexual exploitation of children for financial gain, which involves child prostitution and production of child pornography (Gohir, 2010). Whether the child is physically raped or otherwise touched against their will, or more commonly when the child is bribed, persuaded, tricked, coerced or seduced, the activity is considered sexual abuse. Finkeihor and Korbin (2012) defined sexual abuse as any sexual contact between an adult and a sexually immature child for the purposes of the adult's gratification or any sexual contact to a child made by the use of force, threat, or deceit to secure the child's participation or sexual contact to which a child is incapable of consent by virtue of age or power differentials and the nature of the relationship with the adult. Some sexually abused children may suffer from physical injuries inflicted on the victim due to the use of force to penetrate the private part of the victim. Unwanted touching or penetration in someone's genitals with any object also constitutes sexual abuse. Garba and Kantiok (2015) in their own defined it as a form of child abuse carried out by an adult or older adolescent by sexual stimulation or participation of a child in a sexual act, aimed at physical gratification of financial profits. In recent times, this sexual abuse as a kind of child abuse has been observed by the researchers to has become rampant and still on the increase in many cities in Nigeria, including Ideato North L.G.A of Imo state.

Unlike physical abuse, sexual abuse is much more premeditated and planned by the perpetrator (Meek, 2007). Sexual abuse could occur in the form of incest when a family member is a perpetrator and the pedophile form when the perpetrator is somebody who dominates the life of the victim. This pedophile form involves a perpetrator with a position of responsibility, special gifts and avowed secrecy. Whether a child is victimized by either a person in or outside of the family, the perpetrators of sexual abuse often try to create a special trust or bond with the child. They strive to convince the child that they are special or unique friends and may do so by confiding in the victim or telling the victim of their loneliness to curry help from them.

The process of committing actual sexual abuse typically involves progressive boundary violations. Such boundary violations progress to inappropriate touching of the child and so on. Specifically, a Child Abuse Accommodation Syndrome (CAAS) has been identified among girls who have been repeatedly sexually abused by a male perpetrator over time (National Institute of Mental Health, 2013). This syndrome involves stages of secrecy, helplessness, entrapment and accommodation, delayed, conflicted and unconvincing disclosure and retraction. The common experience of the victims recognized by the CAAS includes the ideas that sexual abuse is always shrouded in secrecy and feelings of helplessness in the victim, fear and ambivalent feelings. Child abuse is also related to child neglect. The phenomenon of child neglect has been nebulous due to limited research and the interchangeable usage of child neglect with child abuse. Neglect is when you fail to give attention to something or someone. According to Spencer (2000), child neglect is the failure to provide for the child's basic needs for food, clothing, shelter, supervision, education and medicare. Dubowitz, Black, Starr and Zuravin (1993) defined child neglect as the failure of a parent or other persons with responsibility for the child to provide needed food, clothing, shelter, medical care, or supervision to the degree that the child's health, safety or wellbeing may be threatened with harm. Furthermore, Aloka and Bimbola (2010) described it as a caregiver's failure to meet a child's basic physical, emotional, medical/dental, or educational needs, or any combination thereof. It has been observed that neglected children always manifest negative attitudes that are against the culture and norms of society which brings about crimes and other social vices, thereby inhibiting societal development. This is possible because children who are victims of neglect have a more difficult time forming and maintaining relationships, coping with trends of the society and adapting to educational development. They are always in fear of associating with other children who can bring them to the limelight to abscond from negative behaviours and ideas. Therefore, child abuse and neglect could be said to be catch-all euphemisms for a variety of childhood injuries believed to be derived from parental acts of omission or commission (Appel, 2009). These abused or neglected children may experience delays in physical and psychosocial development, possibly resulting in psychological problems such as anxiety disorder, low self-concept, disruptive behaviours and depressive tendencies. Indeed, child abuse and neglect are no less than a conundrum of negative forces from morally weak adults that dislocate the very essence of adolescent existence.

The World Health Organization (2014), referring this child abuse and neglect as child maltreatment, noted that it occurs in children less than eighteen years of age. Whether it includes physical, sexual abuse, neglect for commercial or other exploitation, it results in actual or potential harm to the child's health, survival, development or dignity in the context of a relationship of responsibility and trust of power. This makes child abuse and neglect to be regarded as the most common type of maltreatment, with $68 \%$ of known victims in 2000 , out of which $19.3 \%$ were physically abused cases, $10.1 \%$ of sexually abused and $7.7 \%$ of emotional abuse and neglect (Gelles, 1973). In recent times, children are physically or sexually abused and neglected due to the uncaring attitude of parents and guardians who wants to venture into all businesses for money-making and allow other criminal elements to abuse their children and wards who are exposed to a risky, helpless and hopeless condition that can lead to depressive tendencies in an adolescent child especially those in the secondary schools. That is why Pitzner and Drummond (1997) revealed that physical or sexual abuse predicted depressive tendencies in the life of students. Bilge (2014) also opined that physical abuse leads to depressive tendencies among adolescents.

Depressive tendencies are conditions that manifest depression. Depression is defined as an illness that presents an individual with a desolate mood, a loss of interest and pleasure, feelings of guilt or low-self-worth, disrupted sleep pattern, loss of appetite, loss of energy and poor concentration (Famuolaro, Kinscheriif \& Fenton, 1992). Simply, Emekwuru (2016) described it as a state of mind that is characterized by low mood and aversion to activity that can affect one's behavior, thought and sense of well-being. People with depressive tendencies can feel sad, anxious, empty, hopeless, helpless, worthless, guilty, irritable, hurt or restless (Ekechukwu \& Isiguzo, 2019). They may lose interest in activities that were once pleasurable, experience loss of appetite or overeating, have problems concentrating, remembering details or making decisions and may contemplate, attempt or commit suicide (Cole \& Jordan, 2015). Insomnia, excessive sleeping, fatigue, aches, pains, digestive problems or reduced energy may also be present. These could also be described as features of some 
psychiatric syndromes such as major depressive disorders (American Psychiatric Association, 2013). These studies above revealed that adolescent depression can lead to deterioration of sleep quality and daytime disorder. It can develop into suicidal or self-harming ideation or behavior. Adolescents with depressive tendencies also tend to have lower self-esteem, a passive sense of well-being, and poorer social ability. Observations have shown that they are also more susceptible to developing addictions, including internet addictions and substance abuse. All these problems can become ingrained in adolescents and can cause serious problems in their ability to cope with their day-to-day responsibilities, especially in school activities. Therefore, the negative effects of depressive emotions on adolescents should not be overlooked.

For any society to develop, the future must be tailored to such development. The future of such a society is children. The study looked at the rising cases of child sexual and physical abuse and its negative effects on the growing stages of the child's growth in the area of self-confidence, self-esteem and value. Child abuse is gradually metamorphosing into a societal norm; parents, schools, religious body's are adopting child abuse in disguise for discipline, which has led to the depression of children etc.

This is not good for the child who ought to grow into the society, as every abuse hold her harvesting period in the future, our society is having her fair share of this child abuse in various forms, ranging from children killing their mates at school, bulling their mates, committing of suicides etc.

\section{STATEMENT OF THE PROBLEM}

In recent times, child abuse and neglect have become a topical issue in our society. This has manifested in many physical or sexual abuse cases whereby many children fall victims to infanticide, genital mutilation, abandonment, and other ills against the child. All these aforementioned acts of torture and negligence are very harmful to the upbringing, welfare and well-being of any adolescent child despite where he or she is and the intention for which it is carried out. This is because all these cause potential harm to the child's health, survival, dignity and entire developmental process. In any situation, children are witnessing or experiencing abuse, it takes a toll on their entire development. Every adolescent child who has experienced abuse or neglect of any kind will tend to have a response to the trauma. While some suffer long-lasting effects, others are able to recover quickly and with ease. Those who are unable to deal with such strain exhibit some tendencies of being in a depressed state. These depressive tendencies in the lives of these abused or neglected children expose them to so many risks of mental health problems, which result to a posttraumatic stress disorder, alcoholism, shyness especially in women, other social and behavioral problems including avoidance, running away from home, prostitution, cognitive and intellectual deficiencies and even low performance in school work. This issue and its challenges have caused discomfort to many adolescents, especially in the area of study as victims were observed to manifest certain psychological problems that influence their mood, emotions and actions and mar the entire child's development. Therefore, physical and sexual abuses are variables focused in this study to ascertain the level of child abuse and neglect in society. On the heels of this background, the researchers investigated child abuse and neglect as predictors of depressive tendencies among secondary school adolescents in Ideato North Local Government Area of Imo State, Nigeria.

\section{OBJECTIVES}

The study's objectives were to investigate child abuse and neglect as predictors of depressive tendencies among secondary school adolescents in Ideato North Local Government Area of Imo State, Nigeria. Specifically, the study sought to:
1. Ascertain whether physical abuse predicts depressive tendencies among secondary school adolescents

2. Find out the extent to which sexual abuse predicts depressive tendencies among secondary school adolescents

\section{RESEARCH QUESTIONS}

The following research questions guided the study:

1. To what extent does physical abuse predict depressive tendencies among secondary school adolescents?

2. To what extent does sexual abuse predict depressive tendencies among secondary school adolescents?

\section{HYPOTHESES}

The following hypotheses were tested at a 0.05 level of significance

1. Physical abuse and neglect do not predict depressive tendencies among secondary school adolescents in Ideato North Local Government Area of Imo State.

2. Sexual abuse and neglect do not predict depressive tendencies among secondary school adolescents in Ideato North Local Government Area of Imo State.

\section{METHODOLOGY}

The design for this study was correlational because it collected, presented and explained events as they occurred. It also sought to predict the relationship between child abuse, neglect and depressive tendencies among secondary school students in Ideato North Local Government Area of Imo State. The study population comprised all the public and private secondary school adolescents in Ideato North Local Government Area of Imo State. The population consists of thirteen thousand seven hundred and fifteen $(13,715)$ students in secondary schools (Ministry of Education, Owerri, 2020). A sample of 1364 students was used for the study, which formed $10 \%$ of the entire population using the clustered sampling technique. The instruments used were a self-structured questionnaire based on the Likert four-point's scale of strongly agree, agree, disagree and strongly disagree. The titles of the instruments are the Physical and Sexual Abuse Scale (PSAS) and Depressive Tendencies Scale (D.T.S.). It was made of sections, Section A-bio data, B-information on physical and sexual abuse, Section Cinformation on depressive tendencies. The items were ranked as follows Strongly Agree $=4$ points, Agree $=3$ points, Disagree $=2$ points and Strongly Disagree $=1$ point respectively. It was validated by three experts in the department of educational psychology, guidance and counseling. The reliability coefficient of the physical and sexual abuse scale instrument was 0.94 and the depressive tendencies scale was 0.89 using Cronbach alpha statistical method. The research questions and hypotheses were analyzed and tested using the Pearson product-moment correlation coefficient $(\mathrm{r})$. The instruments were administered by the researchers and two trained research assistants. The results came from the answers to research questions and testing of the hypotheses using ANOVA.

\section{RESULTS}

Research Question 1: To what extent does physical abuse predict depressive tendencies among secondary school adolescents?

Table 1: Simple regression on the relationship between physical abuses and depressive tendencies among secondary school adolescents

\begin{tabular}{|c|c|c|c|c|}
\hline $\mathbf{R}$ & $\mathbf{R}^{\mathbf{2}}$ & $\begin{array}{c}\text { Adjusted } \\
\mathbf{R}^{\mathbf{2}}\end{array}$ & $\begin{array}{c}\text { Standard } \\
\text { error }\end{array}$ & $\boldsymbol{\beta}$ \\
\hline 0.82 & 0.67 & 0.54 & 6.53 & 0.40 \\
\hline
\end{tabular}


Table 1 shows regression coefficient $R=0.82, R^{2}=0.67$, adjusted $\mathrm{R}^{2}=0.54$, standard error $=6.53$ while $\beta=0.40$. From the $\mathrm{R}^{2}$ value, it is seen that combined physical abuse accounts for about $67 \%$ of the depressive tendencies amongst adolescent students. The $\beta$ also revealed that as the values of physical abuse increase by a unit, there is a corresponding 0.40 increase in the values of depressive tendency. The value of $\mathrm{R}^{2}$ shows that to a very moderate extent, physical abuse, when combined, predicts depressive tendencies amongst adolescent students.

Research Question 2: To what extent does sexual abuse predict depressive tendencies among secondary school adolescents?

Table 2 shows regression coefficient $\mathrm{R}=0.71, \mathrm{R}^{2}=0.50$, adjusted $R^{2}=0.17$, standard error $=3.19$ while $\beta=0.61$. From the $R^{2}$ value, it is seen that sexual abuse accounts for about $71 \%$ of the depressive tendencies amongst adolescent students. The $\beta$ also revealed that as the values of sexual abuse increase by a unit, there is a corresponding 0.61 increase in the values of depressive tendency. The value of $\mathrm{R}^{2}$ shows that to a very moderate extent, sexual abuse predicts depressive tendencies amongst adolescent students.
Table 2: Simple regression on the relationship between sexual abuses and depressive tendencies among secondary school adolescents

\begin{tabular}{|c|c|c|c|c|}
\hline $\mathbf{R}$ & $\mathbf{R}^{\mathbf{2}}$ & $\begin{array}{c}\text { Adjusted } \\
\mathbf{R}^{\mathbf{2}}\end{array}$ & $\begin{array}{c}\text { Standard } \\
\text { error }\end{array}$ & $\boldsymbol{\beta}$ \\
\hline 0.71 & 0.50 & 0.17 & 3.19 & 0.61 \\
\hline
\end{tabular}

Hypothesis 1: There is no significant relationship between physical abuse, neglect and depressive tendencies among secondary school adolescents in Ideato North Local Government Area of Imo State.

The ANOVA table reveals a calculated $\mathrm{F}$ value of 4.625 and a significant value of 0.043 . Hence, since the sig value $(p=0.043>$ 0.05 ) is less than 0.05 alpha; therefore, the null hypothesis is rejected. It implies that there is a significant relationship between physical abuse, neglect and depressive tendencies among secondary school adolescents. This implies that physical abuse and neglect predict depressive tendencies among secondary school adolescents Ideato North Local Government Area of Imo State.

Table 3: One-way analysis of variance of the relationship between physical abuse, neglect and depressive tendencies among secondary school adolescents in Ideato North Local Government Area of Imo State

\begin{tabular}{|l|c|c|c|c|c|c|c|}
\hline \multicolumn{1}{|c|}{ Particulars } & $\begin{array}{c}\text { Sum of } \\
\text { square }\end{array}$ & df & $\begin{array}{c}\text { Mean of } \\
\text { square }\end{array}$ & F & A & $\begin{array}{c}\text { Significant } \\
\text { value }\end{array}$ & Result \\
\hline Regression & 512.142 & 2 & 256.071 & & & & Significant \\
\hline Residual & 64076.350 & 1.362 & 125.394 & 4.265 & 0.05 & 0.043 & $\begin{array}{c}\text { Hypothesis } 1 \\
\text { Rejected }\end{array}$ \\
\hline Total & 64588.492 & 1.364 & & & & & \\
\hline
\end{tabular}

Hypothesis 2: There is no significant relationship between sexual abuse, neglect and depressive tendencies among secondary school adolescents in Ideato North Local Government Area of Imo State.

The ANOVA table reveals a calculated $\mathrm{F}$ value of 3.656 and a significant value of 0.042 . Hence, since the significance value $(\mathrm{p}=0.042>0.05)$ is less than 0.05 alpha; therefore, the null hypothesis is rejected. This implies that there is significant relationship between sexual abuse, neglect and depressive tendencies among secondary school adolescents. This means that, sexual abuse and neglect predict depressive tendencies among secondary school adolescents in Ideato North Local Government Area of Imo State.

Table 3: One-way analysis of variance of the relationship between sexual abuse, neglect and depressive tendencies among secondary school adolescents in Ideato North Local Government Area of Imo State

\begin{tabular}{|l|c|c|c|c|c|c|c|}
\hline \multicolumn{1}{|c|}{ Particulars } & Sum of square & df & Mean square & F & A & $\begin{array}{c}\text { Significant } \\
\text { value }\end{array}$ & Result \\
\hline Regression & 854.543 & 2 & 427.272 & & & & Significant \\
\hline Residual & 58753.675 & 1.362 & 114.530 & 3.656 & 0.05 & 0.042 & $\begin{array}{c}\text { Hypothesis } 2 \\
\text { rejected }\end{array}$ \\
\hline Total & 64588.492 & 1.364 & & & & & \\
\hline
\end{tabular}

\section{DISCUSSION}

The ANOVA table shows a significant relationship between physical abuse, neglect and depressive tendencies among secondary school adolescents in Ideato North Local Government Area of Imo State since the sig value $p=0.043$ is less than 0.05 alpha level. The findings of this study indicate that child abuse and neglect are predictors of depressive tendencies among secondary school adolescents in Ideato North Local Government Area of Imo State. The findings are consistent with Pitzner and Drummond (1997), which revealed that physical or sexual abuse predicts depressive tendencies in the life of students.

A test on the extent to which combination of physical abuse predict depressive tendencies among adolescent students showed regression coefficient $\mathrm{R}=0.82, \mathrm{R}^{2}=0.67$, adjusted $R^{2}=0.54$, standard error $=6.53$ while $\beta=0.40$. From the $R^{2}$ value, it is seen that combined physical abuse accounts for about $67 \%$ of the depressive tendency among adolescent students. The $\beta$ also revealed that as the values of physical abuse increase by a unit, there is a corresponding 0.40 increase in the values of depressive tendencies. The value of $\mathrm{R}^{2}$ shows that to a very moderate extent, physical abuse, when combined, predict students' depressive tendency among adolescent students. This is in line with the finding of Bilge (2014) who opined that physical abuse leads to depressive tendencies among adolescents.

The findings on sexual abuse, neglect and depressive tendencies among secondary school adolescents also shows regression coefficient $R=0.69, R^{2}=0.48$, adjusted $R^{2}=0.21$, standard error $=3.02$ while $\beta=0.49$. From the $\mathrm{R}^{2}$ value, it is seen that sexual abuse accounts for about $48 \%$ of the depressive tendency amongst adolescent students. The $\beta$ also revealed that as the values of sexual abuse increase by a unit, there is a corresponding 0.49 increase in the values of depressive tendencies. The value of $\mathrm{R}^{2}$ shows that to a very moderate extent, sexual abuse predicts student's depressive tendencies. In testing the hypothesis, the significant value is $=0.042$, which is less than the p-value of 0.05 level of significance. By implication, it shows that there is a relationship between sexual abuse, neglect and depressive tendencies amongst adolescents in secondary schools. The findings concur with previous work by Bilge (2014) in his study, which reported that students generally experienced mild depressive tendencies when abused sexually. WHO (2014) further explained that after sexual abuse, survivors have feelings of 
worthlessness and avoid others because they believe that they have been ruined or molested.

\section{CONCLUSION}

Based on the findings, it was concluded that child abuse and neglect predict depressive tendencies among adolescents in secondary schools in Ideato North Local Government Area of Imo State. It is pertinent for parents and guardians to prevent and protect their children and wards against physical or sexual abuses and neglect that may bring the downfall to be individual and societal progress, among others.

\section{Recommendations}

Based on the findings and conclusion, the following recommendations are posed.

- Local Government Areas should press harder based on established cases for the enactment of state legislation against child abuse and neglect.

- There should be awareness programmes for children through the collaboration of the parents and teachers/caregivers.

- Principals of schools should recognize the roles of educational psychologists and school counselors in the fight and protection of students against any form of child abuse and neglect.

- Parents and guardians should also be adequately enlightened through seminars and workshops by the government, N.G.O.s and local authorities to understand and be able to play their roles in the prevention and protection of their children/ wards against any form of child abuse and neglect at home and in the communities.

\section{ACKNOWLEDGEMENT}

We want to thank the Universal Basic Board of Imo State for their swift approval/ acceptance of this topic. Also, the various school heads of all the senior secondary schools in Ideato Local Government Area of Imo state, sincerely we want to thank you for such swell corporations, it was a memorable one. We will not forget the community for providing such a conducive environment for us to operate as well as the research assistant used to administer the research questions, me labor thank you. Lastly, we want to thank the respondents for their deep concerns and genuine responses to the questionnaire.

\section{AUTHORS CONTRIBUTIONS}

Both of the authors of have contributed equally in the work design and execution.

\section{CONFLICT OF INTEREST}

None.

\section{REFERENCES}

- $\quad$ African Network for Prevention and Protection Against Child Abuse and Neglect. (2000). American Journal of Psychology, 97, 201-321.

- American Psychiatric Association (2013). Depressive disorders. In (5th Ed.), Diagnostic and statistical manual of mental disorders DSM-5. Arlington, Va.

- $\quad$ Aloka, F. B., \& Bimbola, A. N. (2010). Child abuse, effect and preventive measures in Nigerian society. Owerri: Peki Publishers.

- Bilge, A. N. (2014). A guide to theoretical, methodological and empirical assessment in correlational studies. India: Zeriti Bookshop.

- Cole, D. A., \& Jordan, A. E. (2015). Competence memory: Integrating psychosocial and cognitive correlates of child depression. Child Development, 66(2), 459-473. doi.org/10.1111/i.1467-8624.1995.tb00883.x.

- $\quad$ Dubowitz, H., Black, M., Starr, R. H., \& Zuravin, S. (1993). A conceptual definition of child neglect. Criminal Justice and
Behavior $20(1)$,

$8-26$. doi.org/10.1177/0093854893020001003

- Ekechukwu, R. O., \& Isiguzo, B. C. (2019). Predictive determinants of anxiety, depression and stress on athletics performance of students in University of Port Harcourt, Nigeria: Counselling Implications. European Journal of Education Studies, 5(10), 91-99. doi.org/10.46827/ejes.v0i0.2248

- Emekwuru, C. D. (2016). Psychological factors as correlates of post-operative recovery among mastectomy clients in Port Harcourt: Counselling implications (Unpublished master thesis), University of Port Harcourt, Nigeria.

- $\quad$ Ettu, T. U, Ezeribe, S. N., \& Okpoko, I. U. (2015). Sexual abuses of male children in Owerri metropolis, Imo State and implications on youths' reproductive health: Counselling implications. The Counsellor, 34(2), 193-204.

- Famuolaro, R., Kinscheriif, R., \& Fenton, T. (1992). Psychiatric diagnosis of maltreated children: Preliminary findings. Journal of the American Academy of Child \& Adolescent Psychiatry, 31(5), 863-867. doi.org/10.1097/00004583-199209000-00013

- Finkeihor, D., \& Korbin, J. (1988). Child abuse as an international issue. Child Abuse and Neglect, 12(1), 3-23. doi.org/10.1016/0145-2134(88)90003-8

- Garba, F. M., \& Kantiok, S. (2015). Enrolment in Kaduna State: A tool for overcoming gender-based violence/girl child abuse in our secondary schools: Implications for counselling. In A.A. Adegoke, O. Aluede \& G. Ewenyi (Ed.), Issues in the helping profession for Nigerian counselors (pp. 241-251).

- Gelles, R. J. (1973). Child abuse as psychopathology: A sociological critique and reformation. American Journal of Orthopsychiatry, 43(4), 611-621. doi.org/10.1111/i.19390025.1973.tb00830.x

- $\quad$ Appel, J. M. (2009). Mixed motives, mixed outcomes when accused parents won't agree to withdraw care. Journal of $\begin{array}{lll}\text { Medical } \quad \text { Ethics, 35(10), 635-7. } & \end{array}$ doi.org/10.1136/ime.2009.03051

- Meek, W. (2007). Physical abuse and depression: Psychotherapy central. Retrieved October 22, 2014, from http://psychcentra.com/blog/archives/2020/10/02phys ical abuse depression

- Messer, D., \& Jones, F. (2009). Psychology and social care. London: Jessica Kingsley Publishers.

- Ministry of Education Owerri. (2020). Public and private secondary schools in Imo State, Owerri: Ministry of Education Owerri. Owerri, Nigeria: Author.

- National Institute of Mental Health. (2013). Depression. Retrieved October 9, 2020, from http://www.nimhigov/health/ publications/depression/index.html

- $\quad$ Pitzner, J. K., \& Drummond, P. D. (1997). The reliability and validity of empirically scaled measures of psychological/ verbal control and physical/sexual abuse: The relationship between current negative mood and history of abuse independent of other negative life event. Journal of Psychosomatic Research,43(2), 125-142. doi.org/10.1016/s0022-3999(96)00370-4

- $\quad$ Gohir, S. (2010, May 6). The hypocrisy of child abuse in many Muslim countries. The Guardian. Retrieved from http://www.rawa.org/temp/runews/2010/05/06/thehypocrisy-of-child-abuse-in-many-muslim-countries.html

- Spencer, N. (2000). Poverty and child health. Abingdon: Raddiffe Medical Press.

- $\quad$ Waters, E., \& Cummings, E. M. (2000). A secure base from which to explore close relationships. Child Development, 71(1), 164-172. doi.org/10.1111/1467-8624.00130

- World Health Organisation. (2006). Preventing child maltreatment: A guide to taking action and generating evidence. Retrieved from https://www.who.int/violence injury prevention/public ations/violence/child maltreatment/en/ 
Chioma and Ugwumsinachi

Innovare Journal of Education, Vol 9, Issue 2, 2021, 24-29

- World Health Organisation. (2014). Global status report on violence prevention 2014. Retrieved from

http://www.int/violence injury prevention/violence/sta tus_report/2014/en 